\title{
KAJIAN LITERATUR INSTRUMEN ISOMORFIK SEBAGAI ASESMEN PEMBELAJARAN FISIKA
}

\author{
Intan Sumarak Ningsari ${ }^{11}$, Abu Zainuddin ${ }^{1)}$, Woro Setyarsih ${ }^{1)}$ \\ 1)Program Studi Pendidikan Fisika, Fakultas MIPA, Universitas Negeri Surabaya, Surabaya, Jawa Timur, Indonesia
}

Corresponding author : Intan Sumarak Ningsari

E-mail : intan.17030184045@mhs.unesa.ac.id

\section{Diterima 27 Maret 2021, Direvisi 14 April 2021, Disetujui 15 April 2021}

\begin{abstract}
ABSTRAK
Instrumen isomorfik merupakan butir soal yang memiliki representasi berbeda namun memiliki penyelesaian dan konsep-konsep fisika yang sama. Penelitian ini bertujuan mengkaji metode pengembangan instrumen, jenis instrumen isomorfik, media aplikasi instrumen, kemampuan pemahaman konsep siswa, dan materi fisika. Penelitian ini merupakan penelitian studi pustaka menggunakan metode Bibliometrik. Metode pengumpulan data sekunder hasil penelitian, artikel dari berbagai jurnal, dan sumber relevan lainnya pada database Google Scholar dan Scopus dalam kurun waktu 2015-2020, menggunakan aplikasi Publish or Perish (PoP). Langkah penelitian diawali dengan pengumpulan artikel dengan menyeleksi artikel jurnal menggunakan aplikasi PoP, melengkapi atribut artikel melalui software Mendeley, memvisualisasikan pemetaan data menggunakan software VOSviewer berdasarkan judul dan abstrak, dan mendeskripsikan topik kajian penelitian. Hasil kajian dapat disimpulkan bahwa pengembangan instrumen isomorfik digunakan sebagai asesmen sumatif maupun formatif pada pembelajaran fisika, terdiri dari dua jenis isomorfik yaitu isomorphic multiple choice dan isomorphic problem berbasis paper test, dengan media aplikasi instrumen dalam format online (web dan aplikasi), digunakan untuk menganalisis pemahaman konsep, konsistensi, miskonsepsi, mental model, pemecahan masalah fisika, dan hasil belajar siswa. Materi fisika yang sering diujikan menggunakan instrumen isomorfik adalah hukum Newton
\end{abstract}

Kata kunci: instrumen isomorfik; fisika; kemampuan pemahaman konsep

\begin{abstract}
The isomorphic instrument was several questions with different representations but have the same physics concept completion. The studied was purpose to examined development methods instrument, isomorphic types, instrument application media, ability understanding of the concept, and physics theory. This research was a literature study that used bibliometric methods. Methods of collected secondary data from research results, articles journals, and other relevant sources on the Google Scholar and Scopus databases in the 2015-2020 period used Publish or Perish (PoP). The research began with collected and selected journal articles used PoP, completed the article attributes via Mendeley, visualized data mapping used VOSviewer based on title and abstract, and described research study topic. The results of the research can be concluded that isomorphic instrument development is used as a summative and formative assessment on the physics learn consists of two types are isomorphic multiple-choice and isomorphic problem based of paper test with instrument application media in online format (web and application), used for analyzing the understanding of the concept, consistency, misconceptions, mental model, problem-solving, and study result of students by the frequently examined theory are Newton Laws.
\end{abstract}

Keywords: isomorphic instrument; physic; ability understanding of the concept

\section{PENDAHULUAN}

Penilaian merupakan perangkat untuk mengidentifikasi pengetahuan yang telah dimiliki siswa (Kasih \& Purnomo, 2016). Penilaian menurut Permendikbud No 66 tahun 2013 meliputi tiga ruang lingkup kompetensi yaitu kompetensi kognitif untuk mengukur kemampuan berpikir siswa, kompetensi afektif untuk menilai sikap siswa selama pembelajaran, dan kompetensi psikomotor untuk mengukur keterampilan siswa. Paradigma penilaian merupakan sebuah langkah untuk mengidentifikasi pengetahuan berbasis pengujian dengan resiko tinggi (high-stake testing) yang mengacu standar eksternal yang sudah disusun dengan memberikan skor dan ranking untuk membandingkan kemampuan antar siswa sebagai bentuk akuntabilitas. Hal 
tersebut dapat dibuktikan melalui kebijakan pendidikan dengan fokus pada hasil ujian nasional dan ujian-ujian yang diterapkan sekolah sebagai kriteria kesuksesan dalam proses pendidikan. Akan tetapi, penilaian juga dapat digunakan sebagai media untuk menginformasikan pengetahuan dalam memberikan umpan balik agar dapat memperbaiki proses pembelajaran (Kasih \& Purnomo, 2016). Oleh karena itu, aktivitas penilaian proses pembelajaran dan hasil belajar membutuhkan informasi yang heterogen dari setiap siswa (Eis Rahmawati et al., 2020).

Fisika merupakan mata pelajaran dengan konsep berkesinambungan. Salah satu aspek penting dalam pembelajaran bagi siswa adalah memahami konsep. Pembelajaran fisika akan efektif jika dapat memahami bentuk representasi yang berbeda dalam menjelaskan konsep fisika dan mentransfer suatu konsep dari satu bentuk representasi ke bentuk representasi lainnya (Fatmawati et al., 2015). Representasi merupakan sesuatu yang menggambarkan atau menyimbolkan objek atau proses, terdapat beberapa mode representasi yaitu gambar, verbal, grafik, dan matematik. (Fatkhurofi et al., 2015).

Konsep dasar yang identik namun konteks dan penyajian soal dengan representasi yang berbeda dapat menyebabkan perbedaan respon siswa (Sriyansyah, 2015). Kemampuan dalam memahami konsep diperoleh secara teori maupun penerapan dalam kehidupan merupakan wujud dari penguasaan konsep dengan baik (Dyah et al., 2019). Selama ini, siswa mengalami kesulitan menghubungkan satu konsep ke konsep lainnya diakibatkan siswa tidak memahami konsep fisika secara utuh sehingga informasi sebelumnya tidak dapat berkesinambungan dengan informasi baru (Eis Rahmawati et al., 2020). Penyebab kegagalan dalam menyelesaikan permasalahan konseptual yaitu siswa mengalami kekeliruan pemahaman konsep dengan keyakinan bahwa konsepsinya (yang salah) tersebut benar, kegagalan dalam aktivasi pengetahuan fisika yang relevan ke dalam memori ingatannya, dapat menghubungkan pengetahuan sains ke dalam memori ingatan namun gagal mengaplikasikan pengetahuan tersebut untuk menemukan kesimpulan yang tepat, dan mengandalkan intuisi naifnya dikarenakan tidak memiliki pengetahuan fisika yang relevan. (Angin et al., 2017). Kesalahan konsep pada saat menyelesaikan permasalahan mengindikasikan bahwa kekeliruan konsep tidak terbukti ajeg pada tiap permasalahan dengan representasi yang berbeda cenderung 'mendatangkan' pengetahuan yang keliru saat menghadapi soal yang dengan penyelesaian yang sama (Taqwa et al., 2017).

Hasil pembelajaran fisika tidak hanya mengukur kemampuan dalam representasi secara verbal dan matematis, namun juga mengukur kemampuan representasi dalam bentuk gambar dan grafik. Siswa yang dapat menyelesaikan permasalahan dalam bentuk verbal, belum tentu dapat memahami konsep fisika dalam bentuk matematik, gambar, maupun grafik (Ningrum et al., 2015). Setiap siswa memiliki kemampuan spesifik yang lebih dominan dibandingkan dengan kemampuan lainnya. Terdapat siswa yang lebih menguasai kemampuan spasial dan kuantitatifnya dibanding kemampuan verbalnya, tetapi juga terdapat yang berkebalikan. Jika penyajian konsep hanya disusun dari satu atau dua bentuk representasi saja, maka sebagian siswa yang kemampuannya sesuai dengan sajian konsep akan merasa diuntungkan dan yang kemampuannya tidak sesuai dengan sajian konsep, kemampuannya tidak dapat terukur (Widianingtiyas et al., 2015).

Salah satu indikator memahami konsep secara mendalam adalah mengenali, memahami, dan memanipulasi konsep dalam berbagai representasi dengan mampu menyelesaikan beberapa permasalahan dengan konteks dan representasi yang berbeda namun dengan cara penyelesaian yang sama (Nurhasnawati et al., 2018). Oleh karena itu, dibutuhkan instrumen penilaian pengetahuan yang dapat menganalisis berbagai kemampuan siswa dalam bentuk representasi yang berbeda yaitu instrumen tes isomorfik. Instrumen isomorfik adalah bentuk permasalahan dimana dalam satu indikator atau tema butir soal mengandung 3 butir soal dengan penyelesaian konsep yang sama namun bentuk representasi yang berbeda (Tatsar et al., 2017). Beberapa permasalahan disebut isomorfik ketika pemecahan masalah tersebut menggunakan konsep-konsep fisika yang sama dengan langkah-langkah penyelesaian soal yang sama. Pada instrumen isomorfik ini juga dapat memetakan kemampuan siswa dalam pemahaman mode representasi tertentu dan menilai kemampuan siswa dalam mentransfer apa yang dipelajari dari satu konteks ke konteks lainnya.

Mengingat pentingnya instrumen
penilaian isomorfik dalam mengukur
pemahaman dan penguasaan konsep fisika
sebagai produk pembelajaran fisika, perlu
dilakukan pemetaan hasil penelitian tentang tes
isomorfik yang selama ini telah dilakukan dan
tinjauan terkait pengembangan tes isomorfik
sebagai instrumen penilaian pengetahuan


untuk mengukur pemahaman konsep fisika. Pemetaan dilakukan dengan menerapkan analisis Bibliometrik pada fokus kajian kemampuan yang diukur, jenis asesmen, tipe isomorfik, materi fisika yang telah diteliti, metode pengembangan instrumen dan media penyampaian tes.

\section{METODE PENELITIAN}

Metode penelitian ini menggunakan analisis Bibliometrik. Istilah bibliometrik (bibliometrics) dapat ditafsirkan mengukur atau menganalisis literatur dengan pendekatan matematika dan statistika. Analisis bibliometrik merupakan metodologi evaluasi kemajuan pengetahuan melalui literatur dengan kontribusi makalah menggunakan pendekatan statistik (Suprapto N et al., 2020).

Metode pengumpulan data sekunder hasil penelitian artikel jurnal dan proseding conference dalam kurun waktu 2015-2020 melalui aplikasi Publish or Perish (PoP) dilakukan pada bulan november 2020. Pengumpulan literatur dari Scopus dan Google Scholar melalui pencarian berdasarkan judul dan kata kunci pada PoP. Pada Scopus, menggunakan judul "ISOMORPHIC" dengan kata kunci "STUDENT", "PHYSICS", dan "DIFFERENT REPRESENTATION" menghasilkan 4 literatur artikel jurnal. Sedangkan pada Google Scholar menggunakan judul "Isomorfik" dan "Konsistensi" dengan kata kunci "Siswa", "Fisika", dan "Representasi berbeda", diperoleh 30 metadata berupa artikel jurnal, proseding, dan skripsi. Seleksi metadata dilanjutkan dengan batasan berupa artikel jurnal dan artikel proseding, didapat 11 artikel jurnal dan 8 artikel proseding. Hasil seleksi disimpan dalam bentuk RIS dan dikirim ke aplikasi Mendeley untuk diperiksa dan dilengkapi atribut judul dan abstraknya. Seleksi ketidaksinambungan metada dengan topik dilakukan dan diperoleh 13 metadata dengan rincian 9 artikel jurnal dan 4 artikel proseding. Selanjutnya, visualisasi dilakukan VOSviewer berdasarkan kesamaan kata-kata pada judul dan abstrak untuk memperoleh pemetaan variabel-variabel penelitian menggunakan metode perhitungan full counting dengan mengatur jumlah minimum kata yang sama sebanyak 3, sehingga dari 245 kata terdapat 30 item yang terhubung antar artikel. Seleksi item-item yang terdapat pada cluster dilakukan sesuai dengan topik bahasan menghasilkan 4 cluster dengan 11 item. Itemitem yang terdapat pada cluster visualisasi VOSviewer dipilih sesuai topik penelitian kemudian dianalisis dan dideskripsikan. Untuk melengkapi deskripsi tiap topik penelitian dilakukan proses membaca dan mereview setiap artikel jurnal dan artikel proseding yang telah dikumpulkan.

\section{HASIL DAN PEMBAHASAN}

Hasil analisis bibliographic berdasarkan teks data judul dan abstrak dengan perhitungan full counting terlihat pada Gambar 1

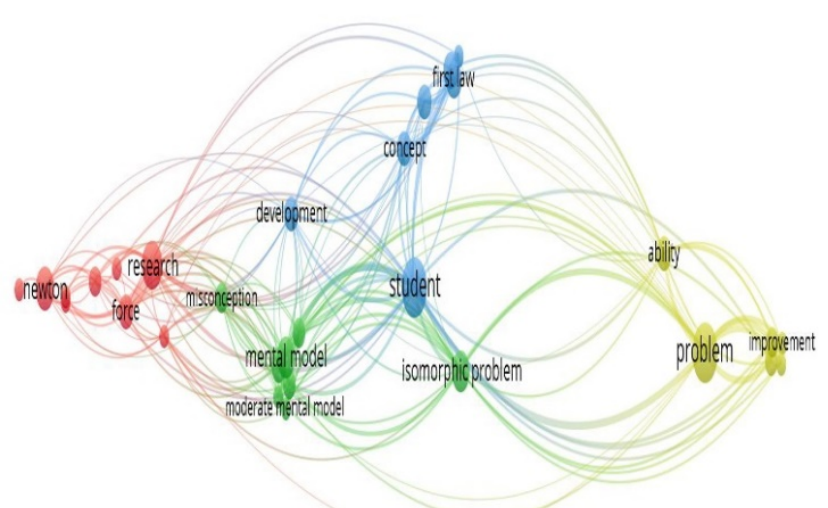

Gambar 1. Visualisasi instrumen tes isomorfik oleh VOSviewer

Berdasarkan visualisasi VOSviewer tersebut, diperoleh 4 cluster dari seluruh itemitem yang sesuai dengan topik kajian penelitian seperti terlihat pada Tabel 1.

Tabel 1. Hasil Pemetaan Clusters

\begin{tabular}{|c|c|c|}
\hline Clusters & Warna & Topik Bahasan \\
\hline 1 & Merah & $\begin{array}{l}\text { Deskriptif kualitatif, } \\
\text { isomorphic test, } \\
\text { force, newton law }\end{array}$ \\
\hline 2 & Hijau & $\begin{array}{c}\text { Mental } \\
\text { model,miskonsepsi, } \\
\text { isomorphic problem }\end{array}$ \\
\hline 3 & Biru & $\begin{array}{l}\text { Concept, } \\
\text { representational } \\
\text { concept, siswa }\end{array}$ \\
\hline 4 & Kuning & Problem, ability \\
\hline
\end{tabular}

Berdasarkan ke empat cluster tersebut, sebagian besar peneliti mengembangkan isomorphic test menggunakan metode deksriptif kualitatif materi gaya dan hukum Newton untuk menganalisis pemahaman konsep dan pemecahan masalah, sedangkan untuk mengetahui mental model dan miskonsepsi pada siswa menggunakan isomorphic problem. Sehingga, dapat dipetakan menjadi topik bahasan berupa metode pengembangan, jenis isomorfik, media, kemampuan yang diukur, dan materi dengan rincian sebagai berikut. 


\section{Metode Pengembangan}

Berdasarkan item pada kluster tersebut dapat dijelaskan bahwa dari 13 artikel yang dianalisis, sebagian besar menggunakan metode penelitian deskriptif kualitatif dengan rincian seperti pada tabel berikut.

Tabel 2. Metode Pengembangan

\begin{tabular}{ll}
\hline \multicolumn{1}{c}{$\begin{array}{c}\text { Metode } \\
\text { Pengembangan }\end{array}$} & \multicolumn{1}{c}{ Peneliti } \\
\hline Deskriptif kualitatif & Viyanti et al, 2017; Indah \\
& Slamet Budiarti et al, \\
& 2017; Paramita et al., \\
& 2018; Nurhasnawati et \\
& al., 2018; Ahmad et al., \\
& 2015; dan D U \\
& Rahmawati et al, 2020 \\
\hline Mixed method & Khasanah et al., 2016 \\
research design & \\
\hline Borg and Gall & Nadhiif et al., 2015 \\
\hline ADDIE & Diyanahesa et al., 2017 \\
& dan Sentot Kusairi, 2019 \\
\hline Mixed Method dengan & Husniyah et al., 2016 dan \\
embedded design & Tatsar et al., 2020 \\
\hline Ex-post facto & Sulistyowati et al., 2017 \\
\hline \multicolumn{1}{c}{ Total } & 13 \\
\hline
\end{tabular}

Penelitian deskriptif kualitatif merupakan penelitian saintifik berorientasi pada objek dan menggambarkan fenomena-fenomena yang ada dengan tujuan mengeksplorasi data, mendeskripsikan data, dan mengeksplanasi data (Galang, 2016). ADDIE (Analyze, Design, Development, Implementation, Evaluation) merupakan model pengembangan melalui 5 langkah yaitu, analisis kebutuhan dan studi pustaka melalui literatur, desain produk yang akan dikembangkan, pengembangan produk isomorfik, pengujian produk yang diterapkan kepada siswa, dan evaluasi dilakukan dengan menilai hasil yang sudah diimplementasikan (Diyahanesa et al., 2017). Penelitian Tatsar (2020) dan Husniyah (2016) menggunakan metode mixed method dengan embedded design dengan langkah pengumpulan data yaitu melakukan pre-test untuk mengukur kemampuan awal, memberikan feedback berupa pembelajaran inovatif, setelah pembelajaran diberikan post-test untuk mengukur kemampuan dari hasil pembelajaran, kemudian wawancara tentang kesulitan siswa.

\section{Jenis Asesmen Isomorfik}

Berdasarkan uraian di atas, terdapat langkah pengambilan data yang dilaksanakan satu kali di akhir pembelajaran, namun juga terdapat langkah pengambilan data sebelum pembelajaran dan akhir pembelajaran, dimana di awal pembelajaran diberikan pre-test, kemudian diberikan feedback atau umpan balik berupa pembelajaran, kemudian diberikan posttest untuk menganalisis apakah feedback yang dilakukan sudah meningkatkan kemampuan siswa. Perbedaan pengambilan data tersebut menggunakan jenis asesmen yang berbeda yaitu asesmen sumatif dan asesmen formatif, dimana asesmen sumatif dilaksanakan di akhir pembelajaran dan sifatnya menyeluruh sedangkan asesmen formatif merupakan salah satu usaha untuk mengukur kemampuan siswa sejak awal hingga akhir pembelajaran (Wahyuni, 2018). Feedback Formatif merupakan balikan berupa gambaran umum mengenai indikator mana yang masih belum tuntas. Feedback yang diberikan kepada siswa dapat melalui pembelajaran inovatif, namun juga dapat langsung dinformasikan pengetahuan yang dimiliki siswa sehingga siswa mengetahui kesalahan konsep dan memperbaiki dengan berlatih mengerjakan instrumen tersebut seperti pada penelitian Sulistiyowati (2017). Selain itu, pada Tabel 1 juga menunjukkan bahwa item isomorphic test merupakan tipe isomorfik isomorphic multiple choice test (pilihan ganda) dan isomorphic problem (butir soal berupa permasalahan dengan pemecahan masalah secara kualitatif). Berikut pengelompokkan jenis asesmen dan tipe isomorfik.

Tabel 3.Pengelompokkan Kategori Jenis Asesmen Isomorfik

\begin{tabular}{|c|c|c|}
\hline $\begin{array}{c}\text { Jenis } \\
\text { Asesmen }\end{array}$ & $\begin{array}{c}\text { Tipe } \\
\text { Isomorfik }\end{array}$ & Peneliti \\
\hline \multirow[t]{2}{*}{ Sumatif } & $\begin{array}{l}\text { isomorphic } \\
\text { multiple } \\
\text { choice test }\end{array}$ & $\begin{array}{l}\text { D U Rahmawati et al, } \\
\text { 2020; Nadhiif et al., } \\
\text { 2015; Ahmad et al., } \\
\text { 2015; Nurhasnawati et } \\
\text { al., 2018; Paramita et al., } \\
\text { 2018; dan Indah Slamet } \\
\text { Budiarti et al, } 2017\end{array}$ \\
\hline & $\begin{array}{l}\text { isomorphic } \\
\text { problem }\end{array}$ & $\begin{array}{l}\text { Viyanti et al, } 2017 \text { dan } \\
\text { Diyanahesa et al., } 2017\end{array}$ \\
\hline \multirow{2}{*}{ Formatif } & $\begin{array}{l}\text { isomorphic } \\
\text { multiple } \\
\text { choice test }\end{array}$ & $\begin{array}{l}\text { Sentot Kusairi, } 2019 \text { dan } \\
\text { Tatsar et al., } 2020\end{array}$ \\
\hline & $\begin{array}{l}\text { isomorphic } \\
\text { problem }\end{array}$ & $\begin{array}{l}\text { Sulistyowati et al., 2017; } \\
\text { Khasanah et al., 2016; } \\
\text { Husniyah et al., } 2016\end{array}$ \\
\hline
\end{tabular}

Untuk lebih memahami makna isomorfik disajikan butir soal pilihan ganda berbasis multiple choice test yang dikembangkan oleh Taqwa (2017) dengan judul penelitian "Konsistensi Pemahaman Konsep Kecepatan dalam Berbagai Representasi" memuat butir soal untuk menentukan kecepatan pada kinematika gerak lurus disajikan dalam representasi yang berbeda pada Gambar 2 


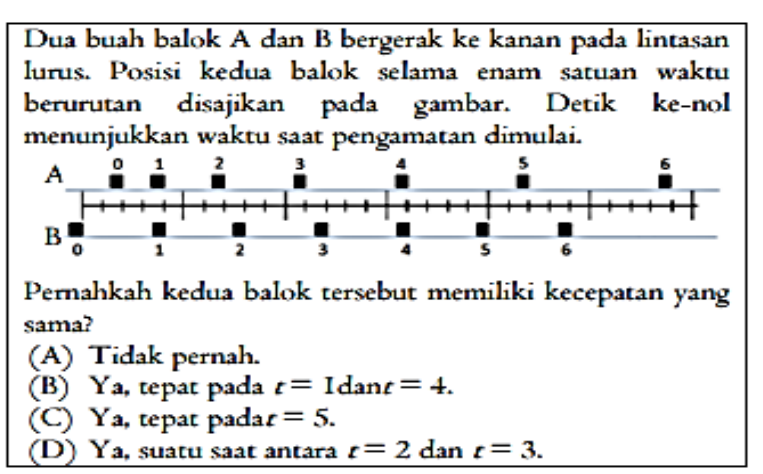

(a)

Posisi benda yang bergerak sepanjang sumbu $x$ dinyatakan oleh persamaan $x(t)=4+3 t-t^{2}, x$ dalam meter dan $t$ dalam sekon. Tanda + menunjuk ke kanan. Kecepatan rata-rata benda selama bergerak dalam interval waktu $0 \leq t \leq 2 s$ adalah ....
(A) $1 \mathrm{~m} / \mathrm{s} \mathrm{kekanan}$
(D) $2 \mathrm{~m} / \mathrm{s} \mathrm{kekiri}$
(B) $1 \mathrm{~m} / \mathrm{s}$ kekiri
(E) $3 \mathrm{~m} / \mathrm{s} \mathrm{kekanan}$
(C) $2 \mathrm{~m} / \mathrm{s} \mathrm{kekanan}$
(F) $3 \mathrm{~m} / \mathrm{s}$ kekiri

(c)
Sebuah bola karet dilepas dari ketinggian tertentu dan memantul lagi sampai posisi semula setelah menumbuk lantai. Kelajuan bola saat tepat menyentuh lantai sama dengan saat tepat meninggalkan lantai, yaitu sebesar 20 $\mathrm{m} / \mathrm{s}$. Lamanya bola mulai menyentuh lantai sampai lepas kembali dari lantai tercatat 0,1 s. Kecepatan rata-rata bolaselamamengenailantaiadalah ....
(A) nol
(B) $10 \mathrm{~m} / \mathrm{s}$ ke bawah
(C) $10 \mathrm{~m} / \mathrm{s}$ ke atas
(D) $20 \mathrm{~m} / \mathrm{s}$ ke bawah
(E) $20 \mathrm{~m} / \mathrm{s}$ ke atas

(b)

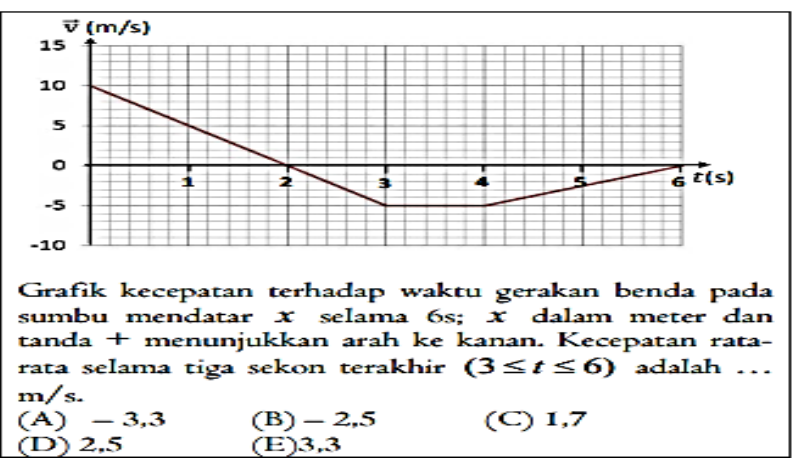

(d)

Gambar 2. Butir soal representasi (a) gambar, (b) representasi, (c) persamaan matematis dan (d) grafik (Sumber : Taqwa, Muhammad Reyza Arief., Hidayat, Arif., dan Sutopo. 2017)

Konsep yang digunakan untuk menyelesaikan permasalahan pada Gambar 3 sama yaitu menentukan kecepatan yaitu perpindahan tiap satuan waktu. Hasil penelitian Taqwa dkk (2017) menunjukkan bahwa masih ada yang memiliki pemikiran bahwa kecepatan itu merupakan posisi tiap satuan waktu, yang terlihat dari alasan menjawab pada representasi gambar dan mengalami kesulitan memahami tanda + atau - pada representasi grafik. Selain itu, isomorphic problem yang telah dikembangkan oleh Nadhiif (2015) dengan judul "Tes Isomorfik Berbasis Komputer untuk Diagnostik Miskonsepsi Diri pada Materi Gaya dan Hukum Newton" mengembangkan dua butir soal dengan penyelesaian konsep yang sama sebagai berikut, dalam

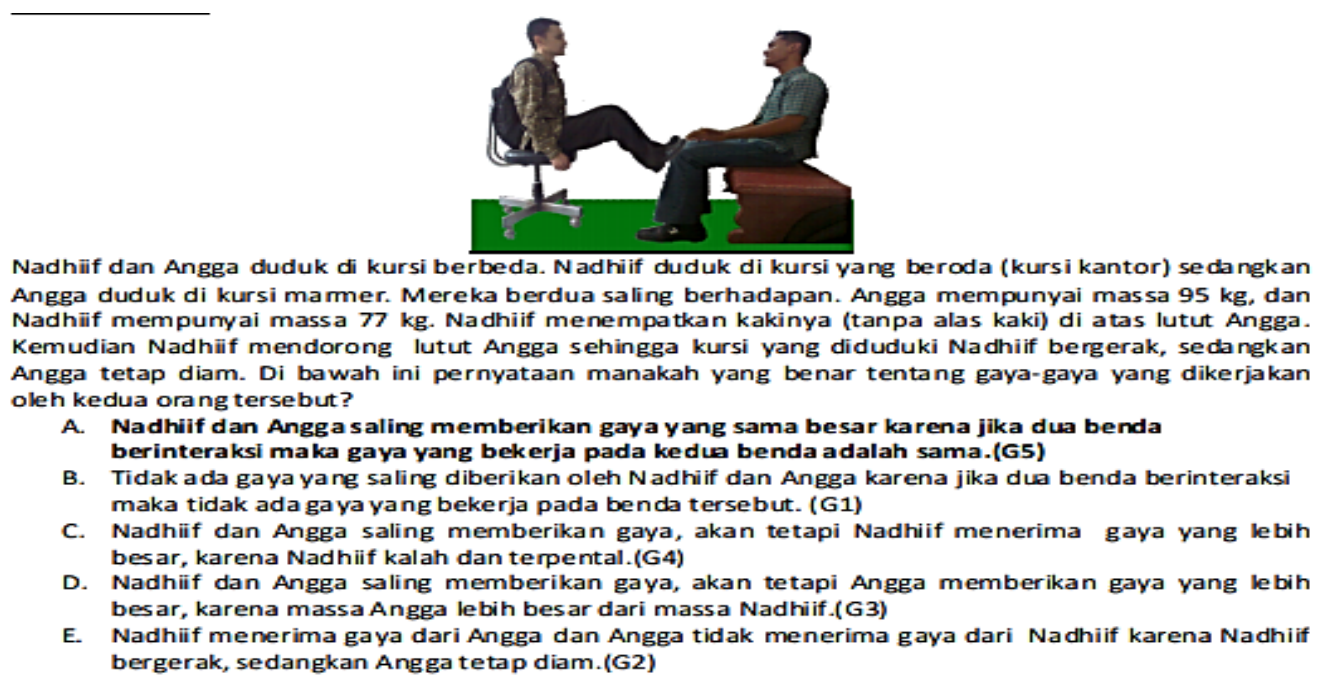

(a) 
Butir kedua.

Dua pegulat sedang bertanding. Pegulat A mempunyai massa $80 \mathrm{~kg}$, dan Pegulat B mempunyai massa $120 \mathrm{~kg}$. Kemudian kedua pegulat tersebut saling mendorong. Tiba-tiba pegulat A terjatuh dan dianggap kalah oleh wasit. Di bawah ini pernyataan manakah yang benar tentang gaya-gaya yang dikerjakan oleh masing-masing pegulat?

A. Pegulat A dan B saling memberikan gaya, akan tetapi pegulat A menerima gaya yang lebih besar, karena pegulat A kalah dan jatuh.(G4)

B. Pegulat A dan B saling memberikan gaya, akan tetapi pegulat B memberikan gaya yang lebih besar, karena massa pegulat B lebih besar darimassa pegulat $A$.(G3)

C. Pegulat A dan B saling memberikan gaya yang sama besar karena jika dua benda berinteraksi maka gaya yang bekerja pada kedua benda adalah sama (G5)

D. Tidak ada gaya yang diberikan oleh pegulat A dan B karena jika dua benda berinteraksi maka tidak ada gaya yang bekerja pada benda tersebut.(G1)

E. Pegulat $A$ menerima gaya dari pegulat $B$ dan pegulat $B$ tidak menerima gaya dari pegulat $A$ karena pegulat $A$ bergerak, sedangkan pegulat $B$ tetap diam.(G2)

(b)

Gambar 3. Butir soal isomorphic problem (a) pertama dan (b) kedua (Sumber : Nadhiif, Muchammad Akbar., Diantoro, Markus., Sutopo. 2015)

\section{Media}

Media pengambilan data berbasis paper test dan online melalui web dan aplikasi. Dari 13 jurnal terdapat 3 penelitian yang berbasis online dengan memanfaatkan teknologi berupa web yang dikembangkan oleh Sentot Kusariri (2019) dan Sulistyowati (2017) berupa web tryout disertai dengan feedback dan aplikasi yang dikembangkan oleh Nadhiif (2015) berupa TIBEKOM. Keuntungan yang didapatkan yaitu hasil kemampuan siswa dapat langsung dideskripsikan sehingga guru dapat merencanakan pembelajaran selanjutnya.

\section{Kemampuan yang Diukur}

Kemampuan yang dapat diukur menggunakan isomorfik sebagai berikut,

Tabel 4. Pengelompokkan Kemampuan yang Diukur

\begin{tabular}{|c|c|c|}
\hline Kemampuan & Frekunesi & Peneliti \\
\hline $\begin{array}{l}\text { Pemahaman } \\
\text { Konsep }\end{array}$ & 1 & Sentot Kusairi, 2019 \\
\hline Konsistensi & 5 & $\begin{array}{l}\text { Ahmad et al., 2015; } \\
\text { Viyanti et al, 2017; } \\
\text { Indah Slamet Budiarti } \\
\text { et al, 2017; } \\
\text { Nurhasnawati et al., } \\
\text { 2018; dan Paramita } \\
\text { et al., 2018; }\end{array}$ \\
\hline Miskonsepsi & 4 & $\begin{array}{l}\text { Nadhiif et al., 2015; } \\
\text { Diyanahesa et al., } \\
\text { 2017; Tatsar et al., } \\
\text { 2020; dan D U } \\
\text { Rahmawati et al, } \\
\text { 2020; }\end{array}$ \\
\hline Mental Model & 1 & Khasanah et al., 2016 \\
\hline $\begin{array}{l}\text { Pemecahan } \\
\text { Masalah }\end{array}$ & 1 & Husniyah et al., 2016 \\
\hline Hasil Belajar & 1 & $\begin{array}{l}\text { Sulistyowati et al., } \\
2017\end{array}$ \\
\hline
\end{tabular}

Berdasarkan Tabel 4 dapat dijelaskan secara mendalam sebagai berikut,

\section{Pemahaman Konsep}

Berdasarkan penelitian Sentot Kusairi (2020), isomorfik digunakan untuk menganalisis pemahaman konsep pada materi Hukum Newton dikategorikan menjadi 3 level, yaitu understand jika dapat menyelesaikan semua butir soal tiap indikator, moderate understand jika menyelesaikan 2 butir soal secara tepat, dan not understand jika hanya menyelesaikan 1 butir soal secara tepat atau semua butir soal salah menggunakan isomorphic multiple choice test berbasis web dengan langsung memberikan feedback kepada siswa berupa indikator apa saja yang kurang dipahami oleh siswa dan guru akan menerima data siswa secara kolektif. Terdapat menu try out dan webvoting yang digunakan untuk berdiskusi antara guru dan siswa dalam mempelajari setiap kesulitan indikator sehingga guru akan merencanakan pembelajaran selanjutnya yang cocok untuk mengatasi kesulitan pemahaman konsep.

\section{Konsistensi}

Pengembangan Isomorphic multiple choice test menggunakan metode deskriptif kualitatif untuk menganalisis konsistensi siswa dikategorikan menjadi 3 kriteria yaitu konsisten jika semua jawaban benar (Skor 2), kurang konsisten jika menyelesaikan 2 soal setiap indikator secara tepat (skor 1), dan tidak konsisten jika hanya menyelesaikan 1 soal secara tepat atau semua soal salah setiap indikator (skor 0 ) dengan rincian sebagai berikut, 
Tabel 5. Kategori Materi Fisika dan Hasil Penelitian Konsistensi

\begin{tabular}{|c|c|c|}
\hline Peneliti & $\begin{array}{l}\text { Materi } \\
\text { Fisika }\end{array}$ & Hasil Penelitian \\
\hline Ahmad et al (2015) & & \multirow{5}{*}{$\begin{array}{l}\text { Tingkat konsistensi siswa masih tergolong rendah dimana siswa yang konsisten } \\
\text { persentasenya } 3 \%-14 \% \text { lebih rendah dari siswa yang tidak konsisten. Hal tersebut } \\
\text { mengindikasikan bahwa siswa masih belum memahami konsep secara keseluruhan } \\
\text { sehingga ketika diberikan soal dengan representasi berbeda siswa bingung untuk } \\
\text { menyelesaikan permasalahan tersebut. Hasil wawancara pada penelitian } \\
\text { Nurhasnawati, dkk (2018), dalam mengerjakan soal isomorfik siswa masih kesulitan } \\
\text { menentukan konsep dasar apa yang digunakan pada setiap butir soal sehingga } \\
\text { mengakibatkan kesalahan dalam menyelesaikan permasalahan. Dan juga terdapat } \\
\text { dua penelitian yang mengukur keterampilan representasi siswa dengan hasil } \\
\text { representasi yang berbeda dimana hasil yang didapatkan berkebalikan. Pada } \\
\text { penelitian Ahmad, dkk (2015) siswa kesulitan memahami bentuk soal secara diagram } \\
\text { sedangkan untuk penelitian Nurhasnawati, dkk (2018) siswa secara keseluruhan } \\
\text { dapat memahami bentuk soal diagram. }\end{array}$} \\
\hline $\begin{array}{l}\text { Indah Slamet } \\
\text { Budiarti et al (2017) }\end{array}$ & $\begin{array}{l}\text { Suhu dan } \\
\text { Kalor }\end{array}$ & \\
\hline Viyanti et al (2017) & Fluida & \\
\hline $\begin{array}{l}\text { Nurhasnawati et al } \\
(2018)\end{array}$ & & \\
\hline $\begin{array}{l}\text { Paramita, Inike et al } \\
\text { (2018) }\end{array}$ & $\begin{array}{l}\text { Gerak } \\
\text { Lurus }\end{array}$ & \\
\hline
\end{tabular}

\section{Miskonsepsi}

Berdasarkan filsafat konstruktivisme bahwa siswa mengonstruksikan pengetahuannya sendiri, maka kemungkinan dapat terjadi kesalahan dalam mengonstruksi mengakibatkan siswa membawa konsep awal fisika yang tidak sesuai (Mulyastuti et al., 2016). Ketidaksesuaian pemahaman konsep siswa dengan konsep ilmuwan sehingga siswa kesulitan memahami konsep fisika yang dipelajari merupakan miskonsepsi (Munawaroh
\& Setyarsih, 2016). Penyebab ketidaksesuaian tersebut dikarenakan setiap siswa memiliki pola pikir dan pengalaman hidup yang beragam sehingga mengakibatkan pemahaman dan penalaran siswa berbeda dengan konsep ilmuwan (Adimayuda et al., 2020). Isomorfik dapat menganalisis miskonsepsi yang terjadi pada siswa sebagaimana terilhat pada tabel berikut.

Tabel 6. Kategori Metode dan Materi Fisika Miskonsepsi

\begin{tabular}{|c|c|c|c|}
\hline Peneliti & Metode & Materi Fisika & Tipe Isomorfik \\
\hline Muhammad Akbar Nadhiif et al (2015) & Borg and Gall & Hukum Newton & Isomorphic multiple choice test \\
\hline $\begin{array}{l}\text { Nadiyah El-Haq Diyanahesa et al } \\
\text { (2017) }\end{array}$ & ADDIE & $\begin{array}{l}\text { momentum dan } \\
\text { impuls }\end{array}$ & Isomorphic Problem \\
\hline Mohammad Zaky Tatsar et al (2020) & Mixed-methods & Fluida Statis & ic multiple choice test \\
\hline D U Rahmawati et al (2020) & Deskriptif Kualitatif & Hukum Newton & \\
\hline
\end{tabular}

Selain metode pengembangan, teknik analisis data juga berbeda dengan rincian sebagai berikut,

Tabel 7. Teknik Analisis Data dan Hasil Penelitian Miskonsepsi

\begin{tabular}{|c|c|c|}
\hline Peneliti & Teknik Analisis Data & Hasil Penelitian \\
\hline $\begin{array}{l}\text { Muhammad } \\
\text { Akbar Nadhif et } \\
\text { al (2015) }\end{array}$ & $\begin{array}{l}\text { Dikelompokkan menjadi } 5 \text { golongan } \\
\text { berdasarkan pilihan jawaban } \\
\text { dengan golongan } 5 \text { siswa } \\
\text { memahami konsep dan golongan } \\
\text { lainnya mengalami miskonsepsi } \\
\text { menggunakan asesmen formatif. }\end{array}$ & $\begin{array}{l}\text { Hasil analisis diagnostik miskonsepsi pada tes } 1 \text { dan tes } 2 \\
\text { untuk semua butir soal masih tergolong rendah dikarenakan } \\
\text { siswa yang menjawab golongan } 5 \text { kurang dari } 75 \% \text {. Namun, } \\
\text { mengalami kenaikan persentase untuk kategorik paham dan } \\
\text { penurunan pada golongan } 2 \text {, golongan } 4 \text {, dan tidak paham. }\end{array}$ \\
\hline $\begin{array}{l}\text { Nadiyah El-Haq } \\
\text { Diyanahesa et al } \\
\text { (2017) }\end{array}$ & $\begin{array}{l}\text { Deskripsi hasil miskonsepsi } \\
\text { dikelompokkan menjadi } 4 \text { kategori } \\
\text { dengan } 4 \text { penyelesaian masalah } \\
\text { tentang materi tersebut. }\end{array}$ & $\begin{array}{l}\text { Hasil analisis jawaban siswa adalah siswa yang mengalami } \\
\text { miskonsepsi masih cukup besar. }\end{array}$ \\
\hline $\begin{array}{l}\text { Mohammad } \\
\text { Zaky Tatsar et al } \\
(2020)\end{array}$ & $\begin{array}{l}\text { Dikategorikan menjadi } 4 \text { kategori } \\
\text { konsepsi yaitu kategori } 4 \\
\text { merupakan konsepsi yang benar } \\
\text { dan kategori lainnya merupakan } \\
\text { bentuk miskonsepsi menggunakan } \\
\text { asesmen formatif. }\end{array}$ & $\begin{array}{l}\text { Pada penelitian ini memberikan umpan balik berupa } \\
\text { pembelajaran authentic learning berbasis fenomena dengan } \\
\text { hasil berupa meningkatnya konsepsi siswa dengan } \\
\text { menurunnya persentase siswa yang mengalami } \\
\text { miskonsepsi. Peningkatan tersebut juga terlihat dari nilai N- } \\
\text { Gain sebesar } 0,52 \text { serta effect size sebesar } 0,42 \text {. }\end{array}$ \\
\hline
\end{tabular}


D U Rahmawati Dikategorikan menjadi 3 kriteria et al (2020) yaitu understand concept Jika menjawab 3 soal benar, miskonsepsi jika menjawab 2 atau 1 soal benar, dan don't understand concept jika tidak ada yang benar
Persentase hasil analisis miskonsepsi sebesar $49 \%$ siswa sudah memahami konsep, $39 \%$ siswa mengalami miskonsepsi dan $12 \%$ siswa tidak memahami konsep.

\section{Mental Model}

Berdasarkan penelitian N. Khasanah et al (2016), instrumen isomorphic problem digunakan untuk menganalisis mental model pada materi dinamika rotasi. Mental model merupakan model yang menggambarkan pikiran seseorang dalam memecahkan permasalahan dan bentuk respon terhadap fenomena atau situasi (Khasanah, $\mathrm{N}$ et al., 2016). Instrumen isomorfik diujikan sebanyak 3 kali yaitu pre-test, kuis, dan post-test. Kemudian, mengkategorikan siswa ke dalam 3 model yaitu Low Mental Model (LMM), Moderate Mental Model (MMM), dan High Mental Model (HMM) sehingga didapatkan hasil bahwa lebih dari $50 \%$ siswa termasuk dalam kategori LMM. LMM termasuk dalam miskonsepsi, siswa masih mengalami miskonsepsi pada momen gaya dan momen inersia.

\section{Pemecahan Masalah}

Pemecahan masalah merupakan salah satu keterampilan pada abad-21 yang berperan penting saat seseorang harus menguasai kondisi baru dengan melibatkan aktivitas yang tidak rutin dilakukan sehingga mampu bersaing dalam segala aktivitas baru ke depannya. Keterampilan pemecahan masalah dianggap memainkan peran penting (Hazninda \& Setyarsih, 2018). Ahfidatul Husniyah, dkk (2016) mengembangkan isomorphic problem sebagai asesmen formatif, dengan umpan balik berupa pembelajaran berbasis masalah untuk meningkatkan keterampilan pemecahan masalah. Melatihkan keterampilan pemecahan masalah penting dikarenakan fisika dapat mendeskripsikan fenomena alam secara ilmiah berupa permasalahan bersifat kontekstual untuk membantu siswa mengembangkan pemecahan masalah siswa dalam bentuk latihan soal (Afandi \& Setayarsih, 2019). Hasil penelitian Husniyah, dkk (2016) berupa analisis kuantitatif kategori sedang berupa uji normalisasi Gain sebesar 0,3 dan effect size sebesar 0,8 sehingga terjadi peningkatan kemampuan pemecahan masalah yang terlihat dari hasil pre-test dan post-test dengan persentase pre-test sebesar $41,75 \%$ dan posttest sebesar $58 \%$. Selain itu, juga menganalisis berdasarkan indikator pemecahan masalah dengan hasil keterampilan pemecahan masalah sebagai berikut,
Tabel 8. Indikator keterampilan pemecahan (Sumber : Ahfidatul et al, 2016)

\begin{tabular}{cc}
\hline $\begin{array}{c}\text { Indikator Pemecahan } \\
\text { Masalah }\end{array}$ & Persentase \\
\hline $\begin{array}{c}\text { Memecahkan masalah } \\
\text { melalui proses berpikir } \\
\text { dasar }\end{array}$ & $84 \%$ \\
\hline $\begin{array}{c}\text { Mengumpulkan fakta } \\
\text { terkait permasalahan }\end{array}$ & $75 \%$ \\
\hline $\begin{array}{c}\text { Menggunakan dan } \\
\text { menguji penyelesaian } \\
\text { alternatif }\end{array}$ & $37.5 \%$ \\
\hline $\begin{array}{c}\text { Menjelaskan solusi } \\
\text { secara sederhana }\end{array}$ & $57.5 \%$ \\
\hline $\begin{array}{c}\text { Menggunakan solusi } \\
\text { secara umum }\end{array}$ & $84 \%$ \\
\hline
\end{tabular}

Berdasarkan Tabel 8, terlihat bahwa siswa masih kurang dalam menguasai proses pemecahan menggunakan penyelesaian alternatif dan menguji penyelesaian tersebut. Kesulitan pemecahan masalah yaitu siswa tidak dapat mengidentifikasikan masalah namun langsung mengaplikasikan pada besaran yang sama yang mengakibatkan siswa tidak dapat memberikan solusi yang benar sesuai konteks yang diberikan (Ahfidatul et al., 2016). Siswa mengalami kesulitan mengidentifikasi konsep pada soal pemecahan masalah mengakibatkan kesulitan dalam menghubungkan antar besaran, menggunakan prinsip dan konsep yang sesuai, menyelesaikan persamaan matematis, dan membuat kesimpulan fisika yang logis (Mufida \& Setyarsih, 2019)

\section{Hasil Belajar Siswa}

Berdasarkan pada penelitian Sulistyowati et al (2017), isomorphic problem sebagai penilaian formatif dengan mengembangkan penilaian Feedback formatif berbasis WEB berupa try out dan webvoting dimana setelah melaksanakan tryout, siswa akan langsung diberikan feedback berupa deskripsi kemampuan siswa secara individu dan guru akan secara langsung menerima hasil kemampuan siswa serta merencanakan pembelajaran selanjutnya untuk memperbaiki kesalahan konsep siswa pada beberapa indikator. Siswa dikelompokkan menjadi 3 kelompok yaitu kelompok 1 tidak mengerjakan try out, kelompok 2 mengerjakan 1-2 try out, sedangkan kelompok 3 mengerjakan 3-4 try out. Hasil penelitian Sulistyowati, dkk (2017) 
menunjukkan bahwa kelompok 3 memiliki nilai yang lebih tinggi dibandingkan kelompok 1 dan 2. Penyebab perbedaan prestasi belajar antara ke tiga kelompok yaitu dengan adanya perbedaan pemberian feedback yang diberikan selama proses pembelajaran dalam memberikan rangsangan kepada siswa untuk meningkatkan hasil belajar dan untuk melatih siswa meyelesaikan soal (Sulistyowati et al., 2017). Pernyataan tersebut sejalan dengan penelitian Koll, Simone (2016) yang menyatakan bahwa feedback mampu memotivasi diri menjadi lebih percaya diri dalam menghadapi ujian sehingga hasil belajar siswa juga meningkat.

\section{Materi}

Melalui studi literatur, persebaran materi dalam tes isomorfik yang diujikan untuk menganalisis kemampuan siswa yang dipersentasekan sebagai berikut,

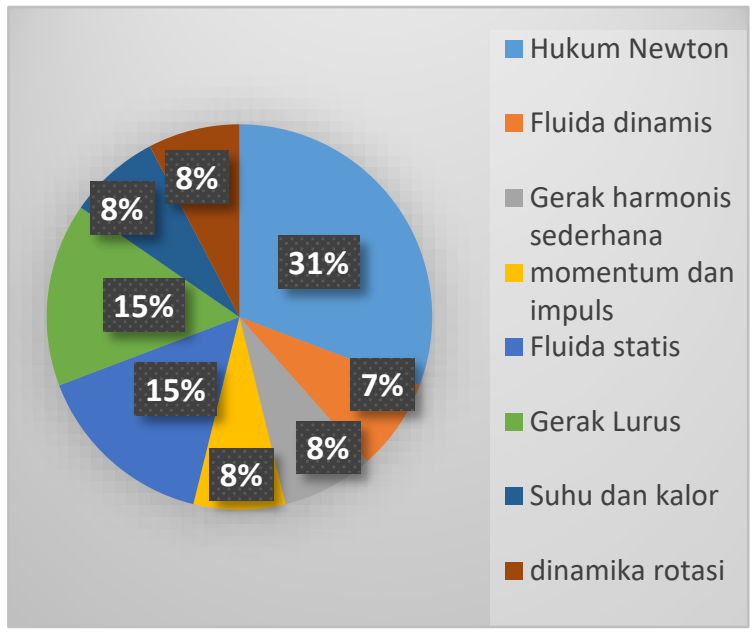

Gambar 4. Persentase Persebaran Materi

Fisika untuk Pengujian Instrumen Isomorfik

\section{SIMPULAN DAN SARAN}

Hasil kajian literatur yang telah dipaparkan di atas, dapat disimpulkan bahwa pengembangan instrumen isomorfik telah digunakan sebagai asesmen sumatif maupun formatif pada pembelajaran fisika, memiliki dua jenis tes isomorfik yaitu isomorphic multiple choice dan isomorphic problem berbasis paper test dan diaplikasikan dalam online (web dan aplikasi) yang dapat digunakan untuk mengukur pemahaman konsep fisika, konsistensi, miskonsepsi, mental model, pemecahan masalah fisika, dan hasil belajar siswa. Materi fisika yang sering diujikan menggunakan instrumen isomorfik adalah hukum Newton.

\section{DAFTAR RUJUKAN}

Adimayuda, Rizal., Aminudin, Adam Hadiana., Kaniawati, Ida., Suhendi, Endi., \& Samsudin., Achmad. (2020). A Multitier
Open-Ended Momentum and Impulse (MOMI) Instrument: Developing and Assessing Quality of Conception of 11th Grade Sundanese Students with Rasch Analysis. International Journal of Scientific and Technology Research, 9(2), 4799-4804

Afandi, Rahmad Alvian \& Setyarsih, Woro. (2019). Analisis Butir Instrumen Problem Solving Berbasis Permasalahan Kontekstual pada Materi Momentum dan Impuls. Inovasi Pendidikan Fisika, 8(3), 814-819

Ahmad, Muslimin., \& Darsikin. (2015). Analisis Konsistensi Respon Siswa SMA terhadap Tes Representasi Majemuk dalam Pembelajaran Fisika Materi Gerak Lurus. Jurnal Pendidikan Fisika Tadulako, 3(3)

Angin, Siprianus L., Sutopo., \& Parno. (2017). Pemahaman Mahasiswa Tentang Multirepresentasi Konsep Percepatan. Jurnal Riset dan Kajian Pendidikan Fisika, 4(1), 48-53

Azninda, Haifa \& Setyarsih, Woro. (2018). Penerapan Model Pembelajaran Problem Based Learning Menggunakan Strategi Self Regulated Learning untuk Meningkatkan Kemampuan Problem Solving Peserta Didik. Inovasi Pendidikan Fisika, 7(2), 347-352

Budiarti, Indah Slamet., Suparmi, Sarwanto, Harjana. (2017). Students' Conceptual Understanding Consistency of Heat and Temperature. Journal of Physic: Conference Series 795012051

Diyanahesa, Nadiyah El-Haq., Kusairi, Sentot., Latifah, Eny. (2017). Development of Misconception Diagnostic Test in Momentum and Impulse Using Isomorphic Problem. Journal of Physics: Theories and Applications, 1(2), 145-146

Dyah, Atika Isnaining., Koes $\mathrm{H}$, Supriyono., Wisodo, Hari. (2019). Bagaimana Penguasaan Konsep Siswa pada Materi Fluida Statis?. Jurnal Pendidikan: Teori, Penelitian, dan Pengembangan, 4(8), 1030-1033

Fatkhurofi, Imam., Mahardika, I Ketut., Lesmono, Albertus Djoko. (2015). Pengaruh Model Pembelajaran Kooperatif Tipe Script dengan Metode Praktikum terhadap Kemampuan Multirepresentasi Siswa dalam Pembelajaran Fisika Kelas $X$ di SMA Muhammadiyah 3 Jember. Jurnal Pendidikan Fisika, 4(2), 140 - 144

Fatmawati., Muslimin., Kade, Amiruddin. (2015). Identifikasi Tingkat Konsistensi Representasi dan Pemahaman Konsep 
Mahasiswa pada Format Verbal, Grafik dan Diagram Dalam Memecahkan Masalah Hukum III Newton. Jurnal Pendidikan Fisika Tadulako, 4(1), 33-38

Gumilang, Galang Surya. (2016). Metode Penelitian Kualitatif dalam Bidang Bimbingan dan Konseling. Jurnal Fokus Konseling, 2(2), 144-159

Husniyah, Ahfidatul., Yuliati, Lia., Muti, Nandang. (2016). Pengaruh Permasalahan Isomorfik Terhadap Keterampilan Pemecahan Masalah Materi Gerak Harmonis Sederhana Siswa Jurnal Pendidikan Sains, 4(1), 3644

Kaniawati, Ida., Fratiwi, Nuzulira Janeusse., Danawan, Agus., Suyana., lyon., Samsudin, Ahmad., \& Suhendi, Endi. (2019). Analyzing Students' Misconceptions about Newton's Laws through Four-Tier Newtonian Test (FTNT). Journal of Turkish Science Education, 16(1), 110-122

Kasih, Putri Anggoro., \& Purnomo, Yoppy Wahyu. (2016). Peningkatan Hasil Belajar Matematika Siswa Sekolah Dasar Melalui Pembelajaran Berbasis Penilaian. Journal of Research and Advances in Mathematics Education, 1(1), 69-78

Khasanah, N., Wartono., \& Yuliati, Lia. (2016). Analysis of Mental Model of Students using Isomorphic Problems in Dynamic of Rotational Motion Topic. Jurnal Pendidikan IPA, 5(2), 186-191

Kusairi, Sentot. (2020). A Web-Based Formative Feedback System Development by Utilizing Isomorphic Multiple Choice Items to Support Physics Teaching and Learning. Journal of Technology and Science Education, 10(1), 117-126

Mufida, Shobrina Nurul \& Setyarsih, Woro. (2019). Keterlaksanaan Model Problem Based Laerning untuk Melatihkan Physics Problem Solving Ability. Inovasi Pendidikan Fisika, 8(3), 855-860

Mulyastuti, Herlina., Setyarsih, Woro., \& J, Mukhayyarotin N. R. (2016). Profil Reduksi Miskonsepsi Siswa Materi Dinamika Rotasi Sebagai Pengaruh Penerapan Model Pembelajaran ECIRR Berbantuan Media Audiovisual. Inovasi Pendidikan Fisika, 5(2), 82-84

Munawaroh, Riyadlotul \& Setyarsih, Woro. (2016). Identifikasi Miskonsepsi Siswa dan Penyebabnya pada Materi Alat Optik Menggunakan Three-tier Multiple Choice Diagnostic Test. Inovasi Pendidikan Fisika, 5(2), 79-81
Nadhiif, Muchammad Akbar., Diantoro, Markus., Sutopo. (2015). Tes Isomorfik Berbasis Komputer untuk Diagnostik Miskonsepsi Diri pada Materi Gaya dan Hukum Newton. Jurnal Pendidikan Sains, 3(2), 58-67

Ningrum, Deni Juwita., Mahardika, I Ketut., Gani, Agus Abdul. (2015). Pengaruh Model Quantum Teaching dengan Metode Praktikum terhadap Kemampuan Multirepresentasi Siswa pada Mata Pelajaran Fisika Kelas $X$ di SMA Plus Darul Hikmah. Jurnal Pendidikan Fisika, $4(2), 116-120$

Nurhasnawati., Wherdiana, I Komang., \& Kade, Amiruddin. (2018). Konsistensi Pemahaman Siswa SMA terhadap Konsep Hukum Newton untuk Representasi Berbeda. Jurnal Pendidikan Fisika Tadulako, 6 (3)

Paramita, Inike., Yennita., \& Fakhruddin. (2018). Analysis of Students Scientific Consitency and Representation Consistency on Rectilinear Motion Kinematics Material Grade X in SMAN 8 Pekanbaru. Jurnal Geliga Sains, 6(1), 918

Rahmawati, D U et al. (2020). Identification of students' misconception with isomorphic multiple choices test on the force and newton's law material. Journal of Physic: Conference Series 1440012052

Rahmawati, Eis., Yuberti., Irwandani. (2020). Pengembangan Instrumen Penilaian Otentik dengan Pendekatan Saintifik pada Pokok Bahasan Gerak Melingkar Kelas X SMA/MA. Gagasan Pendidikan Indonesia, 1(1), 12-23

Rahmawati, Inna Latifa., Hartono., Nugroho, Sunyoto Eko. (2015). Pengembangan Asesmen Formatif untuk Meningkatkan Kemampuan Self Regulation Siswa pada Tema Suhu dan Perubahannya. Unnes Science Education Jurnal, 4(2)

Sriyansyah, S.P., Suhandi, A., Saepuzaman, D. (2015). Analisis Konsistensi Representasi dan Konsistensi IImiah Mahasiswa pada Konsep Gaya Menggunakan Tes R-FCl. Indonesian Journal of Science Education, 4(1), 75-82

Sulistyowati., Sujito., \& Kusairi, Sentot. (2017). Pengaruh Pemberian Feedback Formatif Online Materi Fluida Dinamis Berbasis Isomorphic Problems terhadap Prestasi Belajar Siswa. Seminar Nasional Fisika dan Pembelajarannya

Taqwa, Muhammad Reyza Arief., Hidayat, Arif., dan Sutopo. (2017). Konsistensi Pemahaman Konsep Kecepatan dalam 
Berbagai Representasi. Jurnal Riset dan Kajian Pendidikan Fisika, 4(1), 31-39

Tatsar, Mohammad Zaky., Yuliati, Lia., \& Wisodo, Hari. (2017). Pengembangan FIDTI (Fluid Isomorphic Diagnostic Test Inventory) Sebagai Instrumen Diagnostik Miskonsepsi Fluida. Seminar Nasional Fisika dan Aplikasinya

Tatsar, Mohammad Zaky., Yuliati, Lia., \& Wisodo, Hari. (2020). Eksplorasi Pemahaman Konsep Siswa pada Fluida Statis Berdasarkan Authentic Learning Berbasis Fenomena. Jurnal Pendidikan: Teori, Penelitian, dan Pengembangan, 5(1), 107-113.

Viyanti et al. (2017). Consistency argued students of fluid. Journal of Physic: Conference Series 795012055

Wahyuni, Molly. (2018). Meta Analisis Assessmen Formatif di Pendidikan Tinggi. Journal Cendekia: Jurnal Pendidikan Matematika, 2(1), 62-69

Widianingtiyas, Laras., Siswoyo., Bakri, Fauzi. (2015). Pengaruh Pendekatan Multi Representasi dalam Pembelajaran Fisika Terhadap Kemampuan Kognitif Siswa SMA. Jurnal Penelitian \& Pengembangan Pendidikan Fisika, 1(1), 31-37 